\title{
СУЧАСНІ ПІДХОДИ ДО ВИЗНАЧЕННЯ СУТНОСТІ ТА ОЗНАК ШТРАФНОӤ ВІДПОВІДАЛЬНОСТІ РОБОТОДАВЦЯ ЗА ПОРУШЕННЯ ЗАКОНОДАВСТВА ПРО ПРАЦЮ
}

\author{
КЛЕЦ Тетяна Сергї̈вна - аспірант кафедри цивільно-правових дисциплін \\ юридичного факультету Дніпропетровського державного університету внутрішніх \\ справ
}

УДК 349.2(477)

DOI 10.32782/NP.2021.3.21

\begin{abstract}
У статті розглядаються сучасні підходи до визначення сутності ознак штрафьої відповідальності роботодавия за порушення законодавства про прачю. У прочесі проведеного дослідження запропоновано авторсъке визначення штрабної відповідальності роботодавия, під якою слід розуміти окремий спещіальний різновид трудоправової відповідальності за порушення роботодавцем вимог законодавства про прачю, процедура притягнення до якої, а також розмір $i$ порядок накладення відповідних штрафних санкиій міститься в КЗпП України та Порядку накладення штрафів за порушення законодавства про прачю та зайнятість населення, а саме притягнення до якой унеможливлюе застосування до роботодавиів інших заходів адміністративно- чи кримінально-правової відповідальності. Визначено, що до найважливіших організачійно-правових ознак штрабної відповідальності роботодавия належить: стягнення відбувається тільки за рішенням уповноваженого органу держави (інспекиї, суди тощо); штрафна відповідальність розкривається у бормі штрафу, але підставами притягнення до неї може бути будь-яке протиправне діяння; штраббна відповідальність роботодавия передбачає стягнення з нього платежів на користь держави, при цьому відшкодування збитків прачівникам або іншим учасникам трудових відносин напряму не передбачається; штраббна відповідальність роботодавия може виступати як самостійний вид відповідальності, так і сукупності із більш суворими формами, крім того, вона завжди
\end{abstract}

передбачає сплату певної санкий в матеріальному (грошовому) виразі, який неможливо замінити, а обов'язок сплати такого штрафу замінити зустрічним зобов'язанням.

Ключові слова: штрабна відповідальність, роботодавець, трудове законодавство, матеріальна відповідальність, штрабьі санкиій.

Актуальність дослідження

Відповідальність роботодавця за порушення законодавства про працю - це елемент системи гарантій держави в частині дотримання максимального обсягу конституційних прав людини на використання праці. Роботодавці, виступаючи елементом системи трипартизму, несуть відповідальність перед роботодавцями та державою: перед першими за дотримання трудового законодавства в частині забезпечення індивідуальних та колективних трудових прав; перед державою за дотримання норм та положень, що стосуються організації трудових відносин та використання найманої праці. Дуалізм відповідальності роботодавців не означає дублювання відповідальності чи застосування подвійних санкцій, натомість свідчить про підвищений рівень інтересу з боку держави щодо необхідності дотримання вимог трудового законодавства саме 3 боку роботодавців, або як їх інтерпретує держава - власників засобів виробництва.

Механізм притягнення роботодавців до відповідальності за порушення законодавства про працю передбачає засто- 
сування певних санкцій 3 боку держави та можливості захисту робітниками своїх прав, шляхом компенсації нанесеної діями роботодавця шкоди та/або недоотриманої вигоди. У такому контексті штрафні санкції відіграють важливу роль, оскільки є засобом обтяження роботодавців, і як додатковий стимул для формування в них трудової та фінансової дисципліни задля уникнення негативних наслідків матеріального характеру у випадку порушення законодавства про працю. У системі відповідальності роботодавців за порушення законодавства про працю штрафна відповідальність посідає особливе місце, оскільки передбачає не лише накладання власне обов’язку сплачувати штраф чи виплачувати компенсацію, що має втілюється через застосування державного примусу.

\section{Аналіз останніх досліджень та публікацій}

Науковою основою написання наукової роботи стали наукові праці наступних учених: В. Венедиктова, М. Кельмана, Г. Мурашина, П. Рабіновича, I. Шамшиної, Ю. Шемшученка, А. Явича. Aле проаналізувавши їх дослідження, необхідно зазначити, що на сьогодні немає єдиної думки щодо сутності штрафної відповідальності.

Мета статті - аналіз сучасних підходів до визначення сутності та ознак штрафної відповідальності роботодавця за порушення законодавства про працю.

\section{Основна частина дослідження}

Держава, притягаючи до відповідальності роботодавців, створюе складну систему відносин, а враховуючи наявності моделі трипартизму, де окремими суб'єктами виступають працівник, трудовий колектив, професійні спілки тощо - виникає ситуація, за якої роботодавці несуть ризики застосування одразу декількох видів санкцій за порушення прав та інтересів різних суб'єктів. Тому ми наголошуємо на необхідності на доктринальному рівні визначити зміст та особливість саме штрафної відповідальності роботодавців за порушення законодавства про працю, розглядаючи їі за критерієм суб'єкту трудових відносин, чиї права були порушені роботодавцем. Об’єктивно, що притягає до відповідальності роботодавців тільки держава, оскільки це є обов'язком з точки зору нагляду за додержанням законодавства про працю, а тому процес стягнення всіх штрафних санкцій контролюється державою. Застосування державного примусу неможливо делегувати чи передати на виконання іншому суб'єкту, окрім тим, яких визначає держава, але отримання певної компенсації чи відшкодування за рахунок накладених штрафних санкцій можливо для суб'єктів, чиї права були безпосередньо порушено.

Зауважимо, що сучасний етап розвитку трудового законодавства в Україні орієнтований не на інтереси роботодавців, а тому в більшості випадків держава застосовує надмірні та непомірні санкції до них, чим сприяє фактичному припиненню ними своєї діяльності та використання найманої праці. Інакше кажучи, неоптимальні розміри та неефективні механізми застосування штрафних санкцій до роботодавців сприяють двом негативним тенденціям: тінізації економіки та втрати інтересу у роботодавців до ведення господарської діяльності. Усе це в сукупності несе в собі ризики зростання безробіття та скорочення економічної активності населення.

Саме ці ризики та негативні тенденції необхідно долати засобами вдосконалення трудового законодавства.

Тому I. Лагутіна розглядала штрафну відповідальність роботодавця як засіб захисту прав працівника, оскільки притягнення до відповідальності роботодавців завжди тягне за собою виплату компенсації працівнику. При цьому роботодавець сплачує відповідні санкції і до державного бюджету України, оскільки держава виступає гарантом відшкодування шкоди працівнику, а тому штрафи можна розглядати одночасно як елемент державного примусу і як елемент забезпечення контрольно-наглядової функції держави на ринку праці [1, с. 123]. На нашу думку, такий висновок ученої стосовно призначення штрафних санкцій, які стягуються 
3 роботодавців $є$ недоцільним на сучасному етапі розвитку відносин трипартизму. Держава не повинна перекладати на роботодавців обов'язок утримувати власний апарат, а штрафна відповідальність повинна, у першу чергу, виконувати функції власне відповідальності, а також елемента системи забезпечення законності трудових відносин.

Слід також розглянути тезу про те, що «сутнісна ознака, яка дозволяє відмежувати заходи захисту від санкцій, знаходиться, перш за все, у підставах застосування цих заходів, а не в самих заходах. Якщо застосовуються заходи захисту, то відсутня винна поведінка або захід примусу спрямований на припинення правопорушення, але не проти правопорушника, до нього не застосовуються будь-які позбавлення чи засоби погіршення його правового становища. Відповідальність без вини в галузі трудового права неможлива». Таким чином, заходи захисту, що можуть застосовуватись і у випадках безвинної поведінки порушників, заповнюють певну прогалину в механізмі реалізації примусу в трудовому праві. У юридичній літературі зауважується, що заходи захисту можуть застосовуватись за незначні відхилення від нормального правового порядку, а відповідальність - за правопорушення, які суттево впливають на стан правового порядку [8].

Обгрунтовуючи цю тезу, ми наполягаємо на тому, що трудове законодавство повинно передбачати можливість для усунення недоліків з боку роботодавців у забезпеченні прав працівників. Тобто важливо розуміти, що якщо роботодавець виправляє чи відновлює порушені права працівника самостійно, то в конструкції відповідальності втрачається елемент умислу та негативних наслідків, оскільки фактично вони виправляються, а дії роботодавця спрямовуються на відновлення правового становища працівника.

Спрямованість забезпечення законності у трудових відносинах на приведення трудових правовідносин у фактичну відповідність 3 трудовим законодавством передбачає активну участь суб'єктів трудових відносин у забезпеченні реалізації встановлених правових норм. Так, метою забезпечення законності у трудових відносинах $е$ створення взаємоузгодженості нормативно-правової бази та правозастосовчої практики. До правових засобів забезпечення законності у трудових правовідносинах потрібно відносити чітке врегулювання правовими нормами цих правовідносин, а також законодавче визначення системи ефективних санкцій за порушення правових норм у цій сфері, яка охороняє та захищає ці відносини від правопорушень. Наслідком порушення законності у трудових відносинах є застосування заходів державного примусу. Специфіка примусу як метода соціального управління проявляється в тому, що з його допомогою обмежується або ліквідується свобода функціонування і розвитку об'єкта управління згідно з цілями управлінської системи [7, с. 145]. Отже, застосування державного примусу у вигляді притягнення роботодавця до штрафної відповідальності за порушення трудового законодавства відбувається як крайня міра та використовується лише у встановленому законодавством порядку після того, як правопорушення, допущене роботодавцем, суттєво порушує правове становище працівника, а дії щодо його відновлення з боку роботодавця не вживаються.

у такому випадку державний примус виступає одночасно гарантією дотримання конституційних прав працівника, а також засобом накладання санкцій на роботодавця 3 метою корегування його неправомірної поведінки та уникнення повторного порушення трудового законодавства. але при цьому слід пам'ятати, що державний примус, хоча і втілюється у формі застосування заходів примусового характеру з боку державних органів, але у своїй сутності виступає вираженням примусу волі суспільства стосовно недопущення порушення законодавства, оскільки такий примус засновується на праві, що виключає свавілля з боку держави.

Ми наголошуємо на тому, що сутнісне навантаження штрафної відповідальності роботодавців жодним чином не повинно ототожнюватися із державним примусом. 
Державний примус є формою забезпечення правопорядку в системі трудових відносин, а штрафна відповідальність його окремим проявом, який жодним чином не повинен розглядатися як обтяження для роботодавця, а лише як засіб забезпечення прав працівників. Тобто коли роботодавець самостійно усуває порушення прав останнього, держава повинна виходити iз доцільності застосування додаткової штрафної відповідальності роботодавця, а сама відповідальність не повинна застосовуватися лише з формальною метою задля стягнення штрафних санкцій.

Саме тому нам видається влучним визначення Р. Обручковим матеріальної відповідальності роботодавця як встановлений законодавством обов'язок роботодавця відшкодувати завдану працівникові шкоду (як матеріальну, так і моральну), яка завдана внаслідок неналежного виконання або невиконання роботодавцем покладених на нього обов'язків, зловживання наданими роботодавцеві правами (повноваженнями) або недотримання роботодавцем норм законодавства про працю або охорону праці [4, с. 269]. Якщо відповідальність розглядати як обов'язок, то цілком логічно передбачити, що в системі відносин з приводу притягнення до неї, доцільно заздалегідь забезпечити можливість заміни такого обов'язку комплексом заходів (дій) спрямованих на відновлення порушеного правового становища працівника.

Хоча на думку Ю. Пожарова, якщо матеріальну відповідальність роботодавця за порушення трудового законодавства чи порушення прав працівника визначати як «обов’язок роботодавця відшкодувати шкоду, заподіяну працівникові внаслідок невиконання або неналежного виконання своїх трудових обов'язків, у розмірі і порядку, передбаченому законодавством» [6, c. 138], то можна прийти до висновку, що відновлення чи відшкодування нанесеної шкоди працівнику і буде втіленням штрафної відповідальності роботодавця. Aле ми розуміємо що в такому випадку втрачається сенс штрафної відповідальності як елемента системи державного примусу та державного нагляду за дотриманням законодавства на ринку праці.

Натомість I. Шамшина свідомо уникає терміна штрафна відповідальність, користуючись тільки терміном «матеріальна відповідальність», що мінімізує державний примус, а саму відповідальність переносить у розряд компенсаторних та відновлювальних заходів, які застосовуються роботодавцем не внаслідок примушення до відновлення правового становища, а як власна воля. Тобто дослідниця вважає обов'язком роботодавця надати працівнику майнову компенсацію у разі порушення його трудових прав [9, с. 36]. Але якщо це обов'язок, то він, по-перше, повинен бути кимось покладений, а по-друге - забезпечуватися відповідними компетентними органами держави.

Необхідно відзначити, що для того, щоб сформулювати найбільш повне визначення штрафної відповідальності роботодавця, доцільно проаналізувати не лише наявні доктринальні визначення, а й навести основні ознаки та відмінності цього виду такої відповідальності роботодавця від штрафної (матеріальної) відповідальності працівника. Так, на відміну від матеріальної відповідальності працівника, яку обов'язково пов'язують 3 існуванням трудових відносин, відповідальність роботодавця може виникати і до укладення трудового договору.

Такий стан речей демонструє наявність низки невідповідностей положень КЗпП України вимогам до збалансованості системи трудових відносин, коли працівник та роботодавець знаходяться в однакових умовах, що найменше в контексті системи відносин 3 приводу притягнення останнього до відповідальності, необхідно звернути увагу на наступні системні недоліки сучасного трудового законодавства, які демонструють, що штрафна відповідальність роботодавців виконує саме каральну функцію, а не є ефективним інструментом регулювання трудових відносин і особливо правових конфліктів:

по-перше, положення КЗпП свідчать про те, що законодавець дотримується презумпції невинуватості працівника, i 
жодним чином не дотримується презумпції невинуватості роботодавця. Працівник звільнений від обов'язку доведення вини роботодавця, натомість цим займаються органи державної влади, які через систему відповідних заходів та засобів правового впливу встановлюють вину роботодавця;

по-друге, КЗпП України не містить положення, які 6 свідчили про можливість уникнення роботодавцями відповідальність за порушення законодавства про працю. Так само не містять таких можливостей й інші законодавчі акти, якими передбачена штрафна відповідальність роботодавців: КУпАП, КК України тощо. Тобто штрафна відповідальність - це імператив, який встановлюється державою за порушення роботодавцем формальних ознак трудового законодавства, незалежно від того, чи було здійснено роботодавцем заходи з виправлення такого порушення та відшкодування завданої працівникам шкоди;

по-третє, застосування до роботодавця штрафної відповідальності виступає засобом забезпечення трудових правовідносин, однак застосування такої відповідальності трансформуе трудові відносини в адміністративно-процесуальні; кримінально-процесуальні тощо. Це означає, що порушення роботодавцем законодавства про працю містить у площині трудових правовідносин, а відповідальність за такі правопорушення визначається державою самостійно в інших галузях права, що свідчить про надмірність такої відповідальності та вихід державою за межі функцій юридичної відповідальності.

Штрафна відповідальність роботодавця не має мети покарання, вона направлена не на осудження та обмеження майнового характеру, а на відновлення та виховання. Обмеження майнового характеру застосовуються до правопорушника лише тому, що це необхідно для відновлення майнових прав потерпілого [3, с. 99]. Але ми повинні доповнити точку зору О. Лук'янчикова, звертаючи увагу на те, що у випадку трудових відносин штрафна відповідальність може встановлюватися державою, як система додаткових гарантій недопустимості порушення конститу- ційних прав особи на працю. Встановлення розмірів штрафних санкцій може мати і превентивну мету, демонструючи роботодавцям та іншим учасникам трудових відносин готовність держави застосувати саме такий обсяг державного примусу у випадку порушення трудового законодавства.

На нашу думку, не припустимим є застосування штрафної відповідальності в якості карального заходу, зміщуючи в такий спосіб акцент у контрольних функціях держави 3 відновлювального в бік каральної. Тому ми наголошуємо на тому, що, визначаючи штрафну відповідальність як окрему категорію, ми повинні виходити з того, що це категорія науки трудового права.

Так, наприклад, Н. Левченко вважає, що штрафну відповідальність роботодавця слід розуміти як «обов'язок роботодавця понести матеріальні втрати на користь працівника за порушення ним своїх обов'язків, що спричинило шкоду працівнику майнового чи/і немайнового характеру» [2, с. 79-80]. У свою чергу,O. Аук'янчиков взагалі не розрізняє штрафну та матеріальну відповідальність роботодавця [3, с. 174]. На наше глибоке переконання, такий висновок є хибним, оскільки штрафна відповідальність свідчить про застосування до роботодавця відповідальності у вигляді штрафних санкцій, які можуть мати як цивільно-правовий так і трудо-правовий, адміністративно-правовий і навіть - кримінально-правовий характер.

Дещо іншої думки притримуєтьсяЄ. Подорожній, який хоча прямо і не виділяє штрафну відповідальність роботодавця, однак зазначає на тому, що матеріальна відповідальність не є тільки штрафною, а самі по собі штрафні санкції - це завжди форма державного примусу, яка виражається в примусовому стягненні грошової суми на користь держави, а не на користь суб'єкта трудових правовідносин, чиї права порушені [5, с. 85]. Тотожної точки зору дотримується Г. Чанишева, яка також не виділяе штрафну відповідальність роботодавців, прирівнюючи їі до матеріальної, однак зазначає, що ii існування цілком 
можливе, враховуючи особливість штрафних санкцій як елемента системи державного примусу [7, с. 229]

Таким чином, одні науковці стверджують, що штрафна відповідальність є застосуванням до роботодавця у випадку порушення ним трудового законодавства відповідної санкції за порушення правової норми та негативні наслідки для нього. Інші вважають, що штрафна відповідальність - це правове явище, яке об'єктивується й реалізується в межах особливого, охоронного правовідношення. При цьому єдність наукових підходів полягає в тому, що ніхто не заперечує того, що юридична відповідальність є наслідком порушення нормативних приписів.

Наголошуємо на тому, що штрафна відповідальність не є природною для всіх сторін трудових відносин, і хоча і має багато спільних рис $з$ матеріальною відповідальністю, але застосовується тільки до роботодавця, через те що: виникнення їі не в обох суб'єктів трудових правовідносин, а тільки у роботодавця обумовлено наявністю системи гарантій держави перед працівниками, оскільки в такий спосіб держава реалізує функцію із дотримання повноти конституційних прав особи; суб'єктом є лише роботодавець, що створює відповідну особливу конструкцію правовідносин 3 приводу притягнення до штрафної відповідальності, де працівник ніколи не буде виступати стороною, а лише держава через відповідні органи; відповідальність виникає в результаті винного порушення обов'язків у трудових правовідносинах та порушення роботодавцем законності й правового режиму використання найманої парці;

- штрафна відповідальність не має компенсаційного характеру, оскільки такий характер має матеріальна відповідальність, яка застосовується до обох учасників трудових правовідносин.

Тому доцільно зробити припущення про те, що штрафна відповідальність є узагальнюючою правовою категорією, включає в себе позитивний і негативний аспекти, заходи заохочення та іншого правового стимулювання праці, а також заходи негативного впливу за порушення трудових обов'язків і правових приписів трудового законодавства роботодавцем і вбирає в себе види юридичної відповідальності 3 різних галузей права.

Говорячи про сутність штрафної відповідальності звертаємо увагу на наступні ключові аспекти: підставою такої відповідальності є трудове майнове порушення, тобто винне порушення роботодавцем своїх обов'язків, внаслідок чого було заподіяно шкоду працівнику або порушено правовий режим реалізації права на працю особи; КЗпП закріплює випадки застосування штрафної відповідальності, а тому протиправна поведінка роботодавця може каратися у відповідності до норм та приписів адміністративного, кримінального законодавства тощо; штрафні санкції не можуть бути застосовані до роботодавця в інший спосіб ніж у відповідності до законодавства, винятками є штрафні санкції, що застосовуються за порушення колективних та інших договорів, які укладаються між роботодавцем та профспілковим колективом або трудовим колективом.

Необхідно зазначити, що, на наше переконання, найважливішими організаційно-правовими ознаками штрафної відповідальності роботодавця є наступні:

- по-перше, стягнення відбувається тільки за рішенням уповноваженого органу держави (інспекції, суди тощо). Враховуючи, що аналізований вид відповідальності $\epsilon$ елементом системи державного примусу, то логічно, що його застосування відбувається шляхом реалізації своїх повноважень відповідними контрольно-наглядовими органами. Але законодавець передбачає можливість оскарження такого рішення, а тому кінцевим рішенням може бути не рішення органу перевірки, а рішення суду, яким відповідний державний примус визнається обов'язковим, законним та необхідним;

- по-друге, штрафна відповідальність розкривається у формі штрафу, але підставами притягнення до неї може бути будьяке протиправне діяння. Так, традиційно штрафну відповідальність ототожнюють із адміністративною чи матеріальною, але 
аналіз положень Кримінального кодексу України свідчить про те, що роботодавець несе відповідальність у формі штрафу навіть за кримінальні правопорушення у сфері дотримання правового режиму трудових відносин. Таким чином, штрафна відповідальність є такою, яка охоплює в собі правопорушення роботодавця в різних сферах застосування державного примусу: власне трудоправової, адміністративно-правової, кримінально-правової;

по-третє, штрафна відповідальність роботодавця передбачає стягнення 3 нього платежів на користь держави, при цьому відшкодування збитків працівникам або іншим учасникам трудових відносин напряму не передбачається. Держава не компенсує та не відшкодовує шкоду, але вона здійснюе заходи, спрямовані на виправлення порушеного права працівника шляхом накладання відповідного примусу на роботодавця. У цьому контексті слід наголосити на тому, що штрафна відповідальність у більшості випадків має не стільки відновлювальну, скільки саме каральну функцію, що, на нашу думку, виходить за межі предметного регулювання науки трудового права, а тому передбачає необхідність перегляду самої сутності та правової природи штрафної відповідальності, у бік розширення компенсаторних заходів;

по-четверте, штрафна відповідальність роботодавця може виступати як самостійний вид відповідальності, так і сукупності із більш суворими формами. Сама по собі штрафна відповідальність не може вважатися суворою формою, оскільки пов'язана лише із обмеженням фінансового чи матеріального характеру, які застосовуються до роботодавців, але жодним чином не є персоніфікованими. Іншими словами, штрафна відповідальність застосовується до особи, яка є роботодавцем: юридичної особи, приватної особи (ФОП). Як зрозуміло, до роботодавця у вигляді юридичної особи не можуть застосовуватися кримінально-правові санкції, але вони можуть застосовуватися до посадової особи такого роботодавця, що вже виходить за межі концепту штрафної відповідальності; по-п'яте, штрафна відповідальність завжди передбачає сплату певної санкції в матеріальному (грошовому) виразі, який неможливо замінити, а обов'язок сплати такого штрафу - замінити зустрічним зобов' язанням.

\section{Висновок}

Таким чином, штрафна відповідальність роботодавця є окремим спеціальним різновидом трудоправової відповідальності за порушення роботодавцем трудового законодавства у формі проступку чи злочину, яка застосовується тільки у вигляді державного примусу із покладанням на роботодавця обов'язку сплатити заздалегідь встановлений за відповідне порушення розмір штрафу. Таке розуміння укладається в наступну дефініцію, визначаючи штрафну відповідальність роботодавця як окремого виду трудоправової відповідальності за порушення роботодавцем вимог законодавства про працю, процедура притягнення до якої, а також розмір і порядок накладення відповідних штрафних санкції міститься в КЗпП України та Порядку накладення штрафів за порушення законодавства про працю та зайнятість населення, а саме притягнення до якої унеможливлює застосування до роботодавців інших заходів адміністративно- чи кримінально-правової відповідальності.

\section{入iтература}

1. Лагутіна I.В.Форми захисту трудових прав працівників: дис.. к. ю. н. ; спеціальність 12.00.05 - трудове право; право соціального забезпечення. - Одеса: Одеська національна юридична академія 2007. $-224 \mathrm{c}$.

2. Левченко Н.I. Матеріальна відповідальність роботодавця. Порівняльно-аналітичне право. 2014. С. 78 - 81.

3. Аук'янчиков О.М. Матеріальна відповідальність роботодавця як самостійний інститут трудового права. Порівняльно-аналітичне право. 2013. № 3. С. 173 - 176

4. Обручков Р. І. Відповідальність у трудовому праві: загальний аналіз. Новітні кримінально-правові дослідження. 2015.C. $267-271$ 


\section{АНОТАЦІЯ}

у статті з'ясовано сутність кар'єрного зростання працівника. Проведено комплексний та всебічний аналіз правових засад недопущення дискримінащї при кар'єрному зростанні прачівника. Визначено стан розвитку правових засад недопущення дискримінацї за ознакою статі при кар'єрному зростанні у царині праці та окреслено перспективи їх покращення. Наголошено на необхідності проведення подальших наукових розвідок у напрямку удосконалення правових засад недопущення дискримінацї у світлі сучасного процесу ребормування трудового законодавства.

Ключові слова: правові засади, дискримінація, недопущення дискримінациї, сфера праиі, ознака статі, кар'єрне зростання.

5. Подорожній Є. Щодо зясування правового статусу роботодавця в Україні. Visegrad Journal on Human Rights. 2016. № 1. $152-158$

6. Пожаров Ю. В. Відповідальність роботодавця у трудових правовідносинах. Актуальні проблеми держави і права. 2010. Вип. 52. С. $137-142$

7. Чанишева Г.І. Матеріальна відповідальність роботодавця за проектом Трудового кодексу України. Вісник Південного регіонального иентру Начіональної академії правових наук Украйни. 2016. С. 143-150

8. Черкасов О. В. До питання про розмежування заходів захисту суб'єктивних прав і відповідальності у трудовому праві. Теорія і практика правознавства. 2013. Вип. 2. - URL: http://nauka.jur-academy.kharkov. ua/download/el_zbirnik/2.2013/14.pdf

9. Шамшина I.I. Щодо вдосконалення правового регулювання відповідальності роботодавця в умовах ринкових відносин. Актуальні проблеми права: теорія і практика. 2013. № 26. C. 33-40
Kliets Tetiana Sergiivna, Postgraduate student of the Department of Civil Law Disciplines of the Faculty of Law Dnipropetrousk state University

$$
\text { of Internal Affairs }
$$

MODERN APPROACHES TO DETERMINING THE ESSENCE AND SIGNS OF THE EMPLOYER'S PENALTY FOR VIOLATION OF LABOR LAW

The article considers modern approaches to determining the essence of the signs of criminal liability of the employer for violation of labor legislation. In the course of the research, the author's definition of the employer's penalty liability is proposed, which should be understood as a separate special type of labor liability for violation of labor legislation by the employer. for violation of the legislation on labor and employment, namely the involvement of which makes it impossible to apply to employers other measures of administrative or criminal liability. It is determined that the most important organizational and legal features of the employer's penalty are: recovery is made only by the decision of the authorized body of the state (inspections, courts, etc.); penalty liability is disclosed in the form of a fine, but the grounds for bringing to it may be any illegal act; the penalty liability of the employer provides for the collection of payments from him in favor of the state, while compensation for losses to employees or other participants in the employment relationship is not directly provided; Penal liability of the employer can be both an independent type of liability and a combination of more severe forms, in addition, it always involves the payment of a certain sanction in material (monetary) terms, which can not be replaced, and the obligation to pay such a fine - to replace the counter knitting.

Key words: penalty liability, employer, labor legislation, material liability, penalties. 